\title{
PANORAMA DA TOPONIMIA GALEGA (A TRAVÉS DOS SEUS NOMES MÁIS FRECUENTES) ${ }^{1}$
}

\section{OUTLINE OF GALICIAN TOPONOMASTICS (THROUGH ITS MOST FREQUENT NAMES)}

\author{
Ana Boullón ${ }^{2}$ \\ Universidade de Santiago de Compostela
}

Resumo: O Nomenclátor de Galicia (noroeste da Península Ibérica), con case 40.000 formas, serve de punto de partida para a localización dos topónimos máis frecuentes; unha vez seleccionados, identifícase o seu significado e unifícanse as súas variantes formais: o resultado é unha relación de 83 palabras presentes en topónimos con máis de 50 ocorrencias. Finalmente clasifícanse en áreas semánticas e, a partir delas, ofrécese unha aproximación das principais motivacións que levaron os habitantes a escolleren eses nomes. Case a metade das formas toponímicas fan referencia á intervención humana (núcleos, edificacións, vías...); en segundo lugar, a oronimia, e despois a fitonimia e a hidronimia; un último grupo constitúeno os haxiotopónimos, que reflicten a importancia da relixión na sociedade. A toponimia ofrécenos, en definitiva, unha descrición das principais características físicas, urbanas e ata relixiosas que conformaron historicamente o país.

Palabras-chave: Toponimia; Galicia; Etimoloxía.

1 Este traballo enmárcase no proxecto de investigación Toponimia de Galicia e Portugal (PID2020-114216RB-C61), integrado no proxecto coordinado Toponomasticon Hispaniae, financiado polo Ministerio de Ciencia e Innovación do Goberno de España (MCIN/AEI/10.13039/501100011033/).

2 ana.boullon@usc.gal 


\begin{abstract}
The official catalogue of place names of Galicia, located in the north-west of the Iberian Peninsula, contains almost 40,000 records and serves as a starting point for the most frequent place names. From there, their meaning is identified, and their formal variants are unified: the result is a relation of 83 words present in placenames occurring more than 50 times and finally classified in semantic areas. Subsequently, an approximation of the main motivations that led the inhabitants to choose those names is provided. Almost half of the toponymic forms refer to human intervention (urban area, buildings, roads...). Secondly, the oronymy, then the phytonymy and the hydronymy and finally the last group being made up of hagiotoponyms, which reflects the importance of religion in society. The result is a description of the main physical, urban and even religious characteristics of the country.
\end{abstract}

Keywords: Place names; Galicia; Etymology.

\title{
INTRODUCIÓN
}

Tense dito en diversas ocasións que os topónimos non cumpren a vinculación coseriana entre significante e significado por careceren deste último plano, xa que a súa función é identificar ou designar un lugar³. Daquela, desde o punto de vista sincrónico, o compoñente semántico da súa entidade léxica pode non corresponderse coa súa realidade extralingüística (un lugar chamado Carballeira pode non estar situado nunha carballeira, e o máis probable é que non sexa así). Pero si pode referirse á motivación, á explicación de por que os habitantes chamaron así a un lugar. En palabras de García Sánchez (2011, p. 182): "la motivación es la conexión entre ese apelativo, ese nombre común, dotado de significado, sí, y el referente, la realidad extralingüística, el lugar, que acaba denominándose mediante ese apelativo, convertido desde ese momento en topónimo".

Así, non sempre a orixe etimolóxica ou o significado da palabra coincide coa motivación, e diso o exemplo máis evidente é a toponimia deonomástica. Dentro do conxunto dos topónimos de posesores, xerados a partir dun nome persoal en xenitivo, o topónimo Álvare procede dun nome composto dunha raíz gótica alls 'todo' e outra wars 'coidado, precaución, prudencia"' (Hispano-gotisches

3 Véxase, por exemplo, García Sánchez (2011), Hermo (2017).

39 № 71, NÚM. ESP.|2021, Salvador: pp. 38-75 
Namenbuch de Joseph M. Piel e Dieter Kremer, en diante HGN), pero isto non ten relación ningunha co lugar que nomea, que vén do seu antigo propietario. Semellante é o caso dos topónimos eco, que reproducen outros existentes en lugares distintos: Exipto, Guadalupe, Milmanda (do francés Marmande), Baiona (do francés Bayonne), Rozavales (do pirenaico Roncesvalles), ou dos de repertorio, que os reis medievais escollían para renomear unha poboación (Bembrive/Bembibre < lat. bene vivĕre, Monforte 'monte forte': véxase NAVAZA, 2017, 2020), ou, finalmente, os replicantes, que teñen orixe nun topónimo veciño con algún sufixo diminutivo (Asadelos $<$ Asados, Arenteiriño $<$ Arenteiro, Zamorela $<$ Zamora, Olveiroa $<$ Olveira).

O que pretendo aquí é indagar nas motivacións maioritarias que deseñaron a paisaxe toponímica galega no seu conxunto. Non se me escapa que é un debuxo de trazo groso (ou mesmo moi groso), porque non ten en conta os factores cronolóxicos (a antigüidade dos topónimos), porque o corpus puido ser seleccionado con criterios máis extensivos, como explicarei a seguir, e porque non considerei estritamente semas, senón formas léxicas, polo que as palabras que signifiquen o mesmo pero sexan minoritarias ou opacas non se terán en conta. Pero, en todo caso, penso que, dado o alto volume de datos manexados (o número de lugares aproxímase aos 40.000), pode ofrecer unha visión de conxunto que posibilite coñecer os principais trazos motivacionais que, en última instancia, proporcionarán unha imaxe da xeografía galega, no seu sentido máis amplo: “a superficie terrestre no aspecto físico (relevo, cursos de auga, clima etc.) e nos que se derivan da relación do home co medio (asentamentos humanos, poboación, actividades económicas", segundo é definida polo Dicionario da Real Academia Galega (en diante, $\mathrm{DRAG}^{4}$ ).

\footnotetext{
${ }^{4}$ Esta é a principal fonte lexicográfica utilizada para o significado das voces toponímicas. Subsidiariamente, o Dicionario de Dicionarios (DdD), onde tamén constan palabras que hoxe non se consideran estándares, ou acepcións moi minoritarias. 
Xa noutro momento fixen unha aproximación á paisaxe deseñada polas formas toponímicas máis frecuentes (BOULLÓN, 2020, e antes unha listaxe en BOULLÓN, 2019), pero aquí amplío a selección porque, amais dos que presentan unha variación gráfica (Cima de Vila/Cimadevila), fonética (Gándara/Gandra/Granda), presenza/ausencia de artigo, ou complementos moi recorrentes como de Arriba/de Abaixo e Novo/Vello, inclúo tamén as formas compostas, independentemente do seu segundo elemento - sexa este frase preposicional (Aldea da Fonte, Aldea de Souto), adxectivo (Vilanova, Valcovo), ou outro nome propio (Vilaragonte, Vilarramil)-, as variantes flexionais (singular/plural, masculino/feminino) e as dialectais (Casais/Casás, Chan/Chao, Pazos/Pacios, Quintáns/Quintás) ${ }^{5}$. Considero que desta maneira se reflicte moito mellor a composición dos compoñentes semánticos máis recorrentes na toponimia galega.

A base de partida é o Nomenclátor de Galicia (NG 2003) e as proporcións establécense con respecto ó número de lugares $(37.307)^{6}$. Deles escolléronse os que contaban con máis de 50 ocorrencias, e o resultado foi unha relación de 81 substantivos que superan o $30 \%$ dos nomes dos núcleos habitados. Ponse de relevo o alto grao de variabilidade que presenta a nomenclatura toponímica galega, pois ese $70 \%$ restante presenta formas diferentes en proporción rapidamente descendente: con menos de 5 ocorrencias hai 13.696 topónimos ${ }^{7}$.

\footnotetext{
${ }^{5}$ Aínda se podería facer unha operación máis reducionista, se tamén se considerasen os derivados apreciativos, pero desestimei esta opción, polo menos neste momento, pola súa gran variedade, as diferenzas dialectais e os distintos estratos cronolóxicos dos sufixos apreciativos, case sempre diminutivos (Pereiroá, Eirexúa, Montecelo, Veiguicela, Cotorelo, Fontela, Casaliño, Eirexiña, Airixín, Soutelo, Soutullo, Vilarello, Casarón); ademais, moitos deles poden non ser descritivos, senón replicantes.

${ }^{6}$ Deixei fóra os das parroquias, aínda que as proporcións apenas variaban. Para a toponimia das parroquias, véxase o estudo de Navaza (2009).

${ }^{7}$ Sen ter en conta as formas compostas, e eliminando a variabilidade da presenza do artigo e os adxectivos novo/vello, arriba/abaixo. 
Táboa 1. As palabras máis frecuentes na toponimia galega

\begin{tabular}{|c|c|}
\hline voz toponímica & $\begin{array}{c}\mathrm{n}^{\mathrm{o}} \mathrm{de} \\
\text { lugares }\end{array}$ \\
\hline Vila & 885 \\
\hline Igrexa & 600 \\
\hline Vilar & 545 \\
\hline Outeiro & 540 \\
\hline Castro & 412 \\
\hline Pazo/Pacio & 394 \\
\hline Pena & 365 \\
\hline Campo & 314 \\
\hline Fonte & 295 \\
\hline Casal/Casar & 293 \\
\hline Porto & 271 \\
\hline Souto & 256 \\
\hline Lama & 215 \\
\hline Torre & 205 \\
\hline Río & 198 \\
\hline Piñeiro & 195 \\
\hline Casa & 192 \\
\hline Monte & 170 \\
\hline Quintá/Quintán & 169 \\
\hline Veiga & 166 \\
\hline Costa & 163 \\
\hline Rego & 145 \\
\hline Chan/Chao & 141 \\
\hline Val & 141 \\
\hline Cruceiro & 139 \\
\hline Currás (Curral) & 136 \\
\hline Coto & 135 \\
\hline Aldea & 134 \\
\hline Gándara & 130 \\
\hline Cruz & 128 \\
\hline Cima de Vila & 119 \\
\hline Barreiro & 118 \\
\hline Pereira & 117 \\
\hline Vilariño & 116 \\
\hline Pedreira & 114 \\
\hline
\end{tabular}

\begin{tabular}{|c|c|}
\hline voz toponímica & $\begin{array}{c}\mathrm{n}^{\mathrm{o}} \mathrm{de} \\
\text { lugares }\end{array}$ \\
\hline Carballal & 105 \\
\hline Fraga & 105 \\
\hline Loureiro & 97 \\
\hline Bouza & 96 \\
\hline San Martiño & 93 \\
\hline Barrio & 92 \\
\hline Muíño & 90 \\
\hline Castelo & 89 \\
\hline Carballo & 84 \\
\hline Portela & 83 \\
\hline Laxe & 82 \\
\hline Pereiro & 81 \\
\hline Cal/Canle & 79 \\
\hline Devesa & 78 \\
\hline Ribeira & 77 \\
\hline San Pedro & 76 \\
\hline Regueiro & 74 \\
\hline Seixo & 74 \\
\hline Seoane & 74 \\
\hline Barral & 73 \\
\hline Carballeira & 73 \\
\hline Rúa & 73 \\
\hline Couto & 72 \\
\hline Ermida & 72 \\
\hline Nogueira & 68 \\
\hline Lagoa & 67 \\
\hline Carreira & 64 \\
\hline Graña & 63 \\
\hline Reboredo & 63 \\
\hline Cabana & 62 \\
\hline Igrexario & 61 \\
\hline Barcia/Barxa & 60 \\
\hline Granxa & 60 \\
\hline Santa Baia/Santalla & 60 \\
\hline Paredes & 58 \\
\hline
\end{tabular}

42 № 71, NÚM. ESP.| 2021, Salvador: pp. 38-75 


\begin{tabular}{|l|r|}
\hline \multicolumn{1}{|c|}{ voz toponímica } & $\begin{array}{c}\mathbf{n}^{\mathbf{0}} \text { de } \\
\text { lugares }\end{array}$ \\
\hline San Paio & 58 \\
\hline Pousada & 57 \\
\hline Rial & 57 \\
\hline Sisto & 56 \\
\hline Pumar/Pomar & 55 \\
\hline Parada & 55 \\
\hline
\end{tabular}

\begin{tabular}{|l|r|}
\hline \multicolumn{1}{|c|}{ voz toponímica } & $\begin{array}{c}\text { no } \\
\text { lugares }\end{array}$ \\
\hline Paradela & 55 \\
\hline Quintela & 55 \\
\hline Penedo & 54 \\
\hline Liñares & 52 \\
\hline Mato & 51 \\
\hline
\end{tabular}

Fonte: elaboración propia

O primeiro que podemos salientar desta relación é que son topónimos descritivos, isto é, case todas estas voces teñen aínda hoxe significado transparente ${ }^{8}$, o cal está a falarnos indirectamente da súa cronoloxía, pois as voces máis opacas, que adoitan ser as máis antigas, non se repiten coa frecuencia das que son recoñecibles pola comunidade: a maior opacidade étimo-semántica corresponde maior antigüidade, como enuncia Xaverio Ballester (2014, p. 47).

A clasificación semántica baséase principalmente nas anteriores propostas de García Arias (1995), Trapero (1995) e Terrado (1999), pero adaptada á realidade xeográfica galega. Nos compostos, teño en conta só o primeiro dos elementos, pois é o que designa a realidade a que fai referencia.

Establecín cinco áreas semánticas9: en primeiro lugar, a intervención humana (especialmente agrupamentos de poboación, edificacións ou construcións e comunicacións); despois, a descrición física do territorio, distribuída conforme se refire á terra, á auga ou ás plantas. Finalmente, a presenza do sagrado, cos nomes de santos. Eses serán os grupos comentados nos apartados sucesivos, dos que se expón a súa importancia cuantitativa no gráfico 1. Pero ben entendido que toda clasificación semántica presenta aspectos

\footnotetext{
${ }^{8}$ Non sendo sisto, graña, reboredo, rial, quintá e os diminutivos antigos quintela e paradela (amais dos haxiotopónimos, naturalmente), as restantes aparecen como entradas no DRAG.

${ }_{9}^{9}$ Non uso o concepto coseriano de campo semántico, moito máis restritivo (véxase TRAPERO, 1995, p. 75-78), senón que agrupo os topónimos segundo os significados compartidos. 
discutibles e zonas borrosas. Ademais, topamos aquí co problema da polisemia, posto que un número non desdeñable de palabras pode conter diferentes acepcións, e todas elas con posibles motivacións toponímicas. Tal é o caso de couto 'territorio medieval' / 'terreo acoutado', devesa 'terreo cerrado' / 'bosque de carballos', ou fraga 'terreo boscoso' / 'terreo pedregoso'. Só o estudo de cada topónimo concreto pode dilucidar a que responde. O panorama que presento é, pois, aproximativo, de modo que asignarei as voces á área que me parece máis correspondente á acepción orixinaria ou á máis xeneralizada no territorio.

Gráfico 1: Principais áreas semánticas nos topónimos galegos máis frecuentes

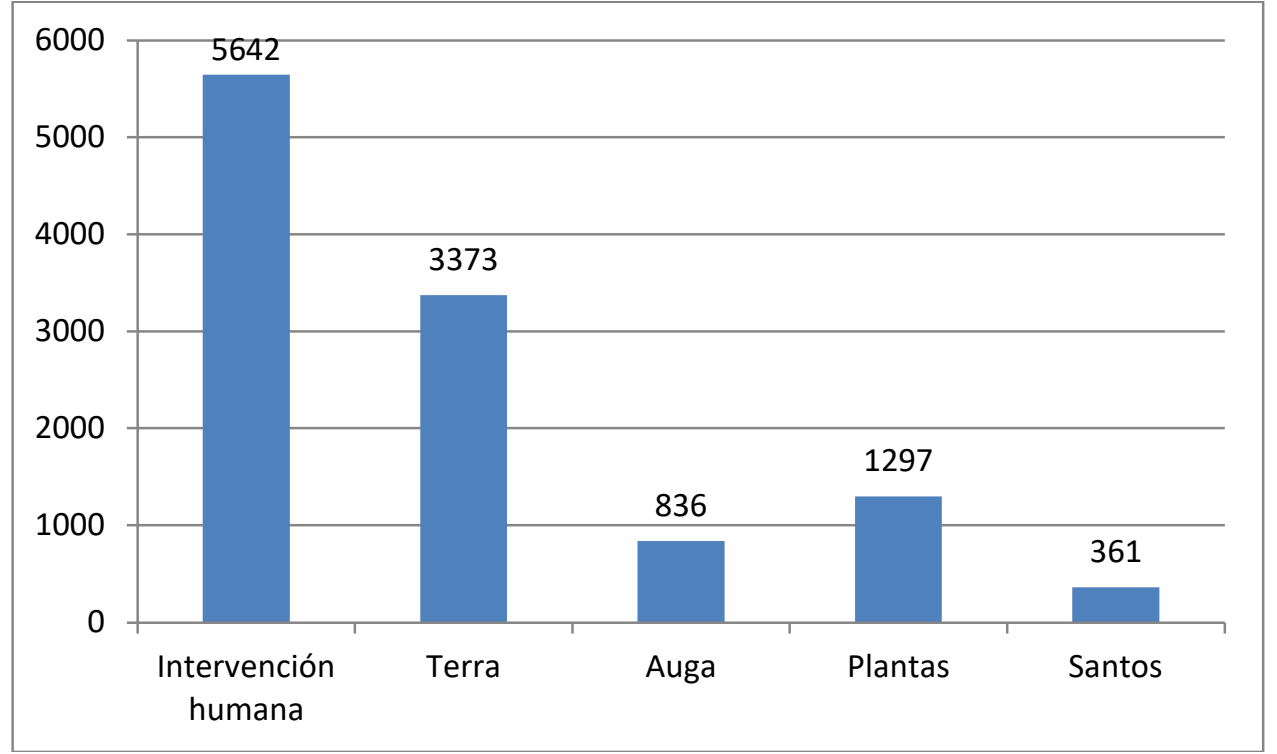

Fonte: elaboración propia

\section{A INTERVENCIÓN HUMANA}

Dicía Xavier Terrado (1999, p. 81) que a acción do ser humano sobre os lugares é o que máis transforma o medio. Efectivamente, son os topónimos que reflicten isto os máis utilizados para a descrición da paisaxe. Incluímos as voces referidas á intervención humana directa na paisaxe: agrupación de vivendas (núcleos habitados, partes da aldea), construcións (para a habitación, para a 
defensa, para actividades agropecuarias e comerciais, para a condución de auga...) e, ademais, as vías de comunicación. Todos eles en moi diferente proporción, como se ve no gráfico 2.

Gráfico 2: A intervención humana na toponimia

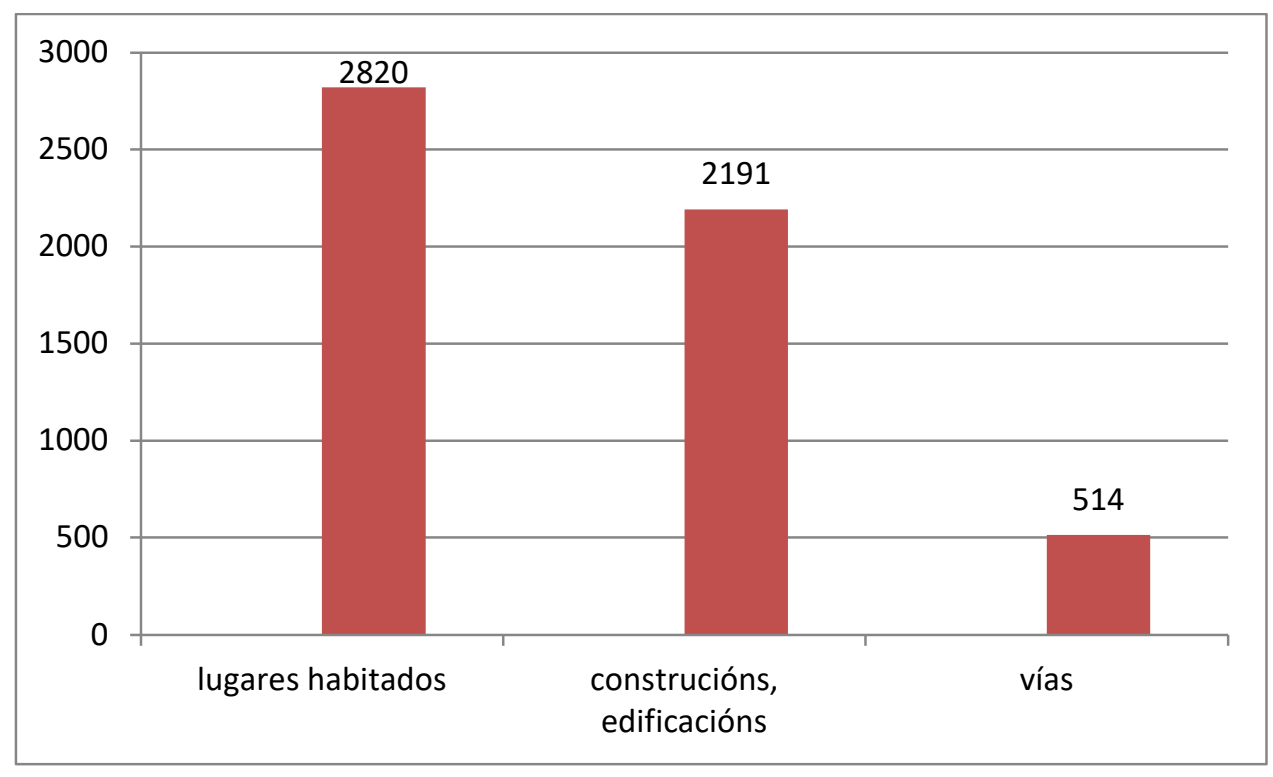

Fonte: elaboración propia

1.1 Lugares habitados: vila, vilar, castro, casal, quintálquintán, aldea, cima de vila, vilariño, barrio, quintela; igrexario

A palabra máis repetida no corpus é vila, pero cómpre ponderar que esta situación deriva dos criterios seguidos para a contaxe: moitos dos compostos están formados con nomes de posesor, o que implica unha alta variabilidade e a aparición de formas non transparentes ${ }^{10}$. Como indiquei noutro lugar (BOULLÓN, 2017), os topónimos procedentes de nomes persoais chega a acadar o $21 \%$ das formas toponímicas galegas. Dentro delas, o recurso máis frecuente é a utilización do xenitivo latino (Vilalvite, do nome latino Alvitus, Vilastrille, do

10 Exclúo Viloira/Viloura e Vilaza, prerromanos (BASCUAS, 2006; 2014) e Villestro, de etimoloxía escura, posiblemente tamén prerromana. 
feminino xermánico Astroildi, etc.). Fóra destes, hai algúns compostos con adxectivos que se repiten moito: Vilaboa 29, Vilachá 26/Vilachán 7, Vilacova 9, Vilamaior 28/Vilamor 7, Vilameá 27/Vilameán 6 (< mediana), Vilasuso 23 (< sursu), Vilaverde 34, e o máis deles, Vilanova 120.

Folga seguramente dicir que o concepto de vila era diferente do actual, como tamén o eran outras das voces máis empregadas toponimicamente. Todas elas definen diversas formas do poboamento rural tradicional galego, non sempre fáciles de delimitar entre elas. As villae no mundo romano eran pequenas explotacións agropecuarias, que foron evolucionando na Galicia tardorromana e altomedieval a verdadeiras aldeas, de forma que na Alta Idade Media constituíron a célula de poboación hexemónica. Ata o século XIII continuou un proceso de polinuclearización e atomización do poboamento, en relación posiblemente cunha maior presión demográfica e coas esixencias señoriais de intensificar a produción para satisfacer a renda feudal (SÁNCHEZ PARDO; RODRÍGUEZ RESINO 2009, p. 145). A maiores desta denominación foron aparecendo outras que posiblemente indicaban en principio asentamentos secundarios: casal/casar (e os plurais casás, casais, casares), vilares, vilariños, quintás/quintáns (e o seu diminutivo quintela). Pola súa abundancia e ambigüidade semántica deterémonos un chisco nesta última serie.

Aínda que está claro que deriva do numeral latino quintus, $-a,-u m$, o seu significado foi obxecto de diversas hipóteses. Para Lange (1966, apud VARELA SIEIRO, 2008, p. 69) xurdiu a partir de expresións como uilla quintana ou casa quintana, de onde 'casa señorial' ou 'residencia onde vive o señor'. Álvarez Maurín (1994, p. 310) considera unha evolución do significado de quinta 'quinta parte da produción que se pagaba en arrendamento' a 'herdade', 'predio rústico'. En todo caso, Xaime Varela (2008, p. 70-72) infire tres acepcións a partir dos textos: 'finca rústica con vivenda', 'terreo de cultivo' e 'terreo que rodea unha vivenda'. Quintela (xunto á variante Quintenla) é derivado desta voz, como 
demostran as atestacións Quintanella a.897, Quintanela a.975, Quintaela a.1228 e semellantes ${ }^{11}$.

Cima de Vila expresa unha parte da poboación, o grupo de casas que está no lugar máis alto; oporíase a fondo de vila, o que está no máis baixo, e a cabo de vila, a parte oposta á entrada principal (MARQUÉS, 2018, p. 48).

O caso de castro é diferente, porque, aínda que é voz de orixe latina (castrum), nomea os poboados prerromanos fortificados, situados en lugares estratéxicos e defendidos con sólidas murallas ${ }^{12}$. Estímase que hai restos de cinco mil castros, o que indica unha poboación moi intensa e asemade dispersa na Galicia daquela época (LÓPEZ CARREIRA, 2016, p. 73). A fonda transformación social, económica e cultural que supuxo a romanización motivou que moitos daqueles poboados foran abandonados (aínda que algúns continuaron ata hoxe), nun proceso lento que durou varias centurias, e que se constata mediante restos arqueolóxicos alén das murallas, ou novas entidades situadas a certa distancia dos castros orixinais, posiblemente por estaren máis preto das terras cultivadas, das vías de comunicación e por consideraren obsoletas as antigas poboacións. Os castros foron virando en aldeas castrexas galaicorromanas ${ }^{13}$ entre os séculos I e III despois da nosa era: estruturas cuadrangulares, rúas rectas, cubrición con tellas e, sobre todo, ausencia de murallas. Finalmente, moitos mudaron de localización, aínda que os orixinais mantivéronse no imaxinario popular galego como enclaves onde residía o elemento sobrenatural: tesouros, portas máxicas, mouras de cabelos louros, sucesos extraordinarios...; mesmo algúns foron

\footnotetext{
${ }^{11}$ Para as atestacións na documentación medieval latina o recurso utilizado é o imprescindible Corpus Documentale Latinum Gallaeciae (CODOLGA). Para a romance, o Corpus Xelmírez e o Gallaecia Monumenta Historica (GMH).

${ }^{12}$ Terei en conta aquí esta acepción, aínda que é un termo bastante polisémico (na Alta Idade Media podía denotar unha villa, un antigo castro reutilizado, un castelo e, ocasionalmente, un territorio: vid. Ayala Martínez, apud LIXÓ GÓMEZ, 2020, p. 73). Presenta unha estreita conexión cos castella, como veremos máis adiante.

${ }^{13}$ Denominación proposta por José Carlos Sánchez Pardo (2010a, p. 133) no traballo que sigo nesta parte.

47 № 71, NÚM. ESP.|2021, Salvador: pp. 38-75 
sacralizados mediante a construción de ermidas. E moitas destas novas entidades seguiron levando o nome Castro. Hoxe, 412 aldeas comezan con este substantivo (máis tres concellos: Castro de Rei, Castroverde, Castro Caldelas, e 31 parroquias), amais de dous O Crasto e tras preposicións (Sucastro/Socastro 25, Trascastro 10, Tras do Castro 3). Aínda poderiamos engadir os diminutivos Castrelo(s) 26, un Cristelos, Castroncelos e dez Castriño (mesmo dous redundantes Castro Castriño).

A aldea, préstamo árabe (do andalusí aḍáy'a, clásico dáa'ah, segundo Corriente), ten presenza relativamente tardía na documentación galega (a.1147), se ben que para referirse a núcleos galegos só aparecen no século XIII ("in aldea de Pineyra de predicto monasterio" a.1223, Ferreira de Pallares). En galego o significado é semellante ao que tiña en árabe: 'núcleo pequeno de poboación, de carácter rural e con poucos veciños', e a partir da súa introdución no territorio tivo unha gran difusión, como evidencia o seu lugar nesta lista, con 134 ocorrencias.

Barrio está catalogado aquí como 'parte dunha poboación', porque esta é a acepción que ten na actualidade, pero é moi posible que tal acepción sexa máis recente cá orixinaria. Como xa expuxen en Boullón (2019, p. 286-287), é dubidoso que en Galicia esta palabra proceda do árabe coa acepción 'arrabaldo' ou 'aldea pequena', posto que o seu significado na documentación latina é máis ben 'campo': Bascuas (2014, p. §25.1), con argumentos sólidos, considérao derivado de barro e, por tanto, de orixe prerromana.

A voz igrexario (que na toponimia presenta unha variante minoritaria Grixario 5) non se refire a un lugar habitado, senón a un territorio administrado por unha autoridade: designa o 'conxunto de terras que pertencen a unha igrexa'. Da importancia na sociedade galega da institución relixiosa dá conta tamén a voz igrexa, no seguinte apartado. 


\subsection{Construcións, edificacións: igrexa, pazo/pacio, torre, casa, castelo, ermida, graña, cabana, granxa, paredes, pousada, muíño, cal/canle}

A igrexa é a edificación que deu lugar a máis topónimos, dada a súa condición de centro físico da parroquia. Son numerosas as variantes rexistradas no NG: Igrexa, a máis frecuente, é a restitución coa forma estándar das moi abundantes castelanizacións Iglesia; pero tamén hai numerosas formas populares, como Eirexa 64, Airexa 7, Eirexe 116, Airexe 37, Grixa 9, Gris 2, Eirixe 15, Eirixa ${ }^{14}$. A outra construción de tipo relixioso neste elenco é ermida (< lat. eremìta).

A denominación para a "construción destinada a vivenda" máis usual é casa, do latín casa 'cabana', que desprazou a clásica domus desde o séc. VIII, século en que se constata a súa aparición nos textos galegos medievais: "serviat ad dominos de casa de Samanos" (Samos, a.785). Xaime Varela (2008, p. 128-149) no seu detallado estudo desta voz na documentación latina, destácaa como unha das palabras de maior relevo no seu corpus. Tamén no NG é moi común: forma parte de case 400 topónimos; nesta cifra inclúese un dos seus compostos, Casanova (170), co seu plural, As Casas Novas (56) ${ }^{15}$.

Pazo (ou a variante pacio) ${ }^{16}$, a segunda voz en cantidade neste grupo, é moito máis frecuente na Gallaecia que noutros ámbitos hispánicos e ata románicos (vid. MORALEJO, 2008, p. 293-4). Evidentemente, o significado designado na toponimia por estes descendentes do latín palatiu- non era a latina de 'residencia real', nin tampouco a adquirida moito máis tarde 'casa grande, antiga e nobre, especialmente a situada no medio rural', senón que se refería á

${ }^{14}$ Véxase Santamarina (2008) para a explicación destas formas, e en xeral para a influencia relixiosa na toponimia.

${ }_{15}$ Outros compostos moi repetidos son casa(s) vella(s), casa(s) do monte, casa grande, casa soa, casa do vento. Non inclúo os topónimos formados con cas, forma curta de casa (Casdemiro, Cascaxide, Casvasco, Caspedro, etc.), nin coa variante palatalizada Cacha- (Cachagonza, Cachaldora, Cachamaría...).

${ }^{16}$ Na nómina inclúese tamén a variante fonética que presentan Os Paces (2). E ampliaríase máis se considerásemos os derivados Pazó (2) (< palatiolos) e Paciños (2). 
vivenda de alguén eminente social ou economicamente. Segundo López Ferreiro (1895, p. 561-2), a antiga villa adoitaba estar dividida en dúas partes, unha reservada ao señor (dominicum, palatium, paaço, turris) e a outra subdivida en varios casais destinados aos $\operatorname{colonos}^{17}$. A variante dialectal pacio está pouco atestada na Idade Media ${ }^{18}$ e actualmente localízase en boa parte da provincia de Lugo, como se ve no mapa 1.

\section{Mapa 1: Pazo/Pacio na toponimia de Galicia (PTG)}

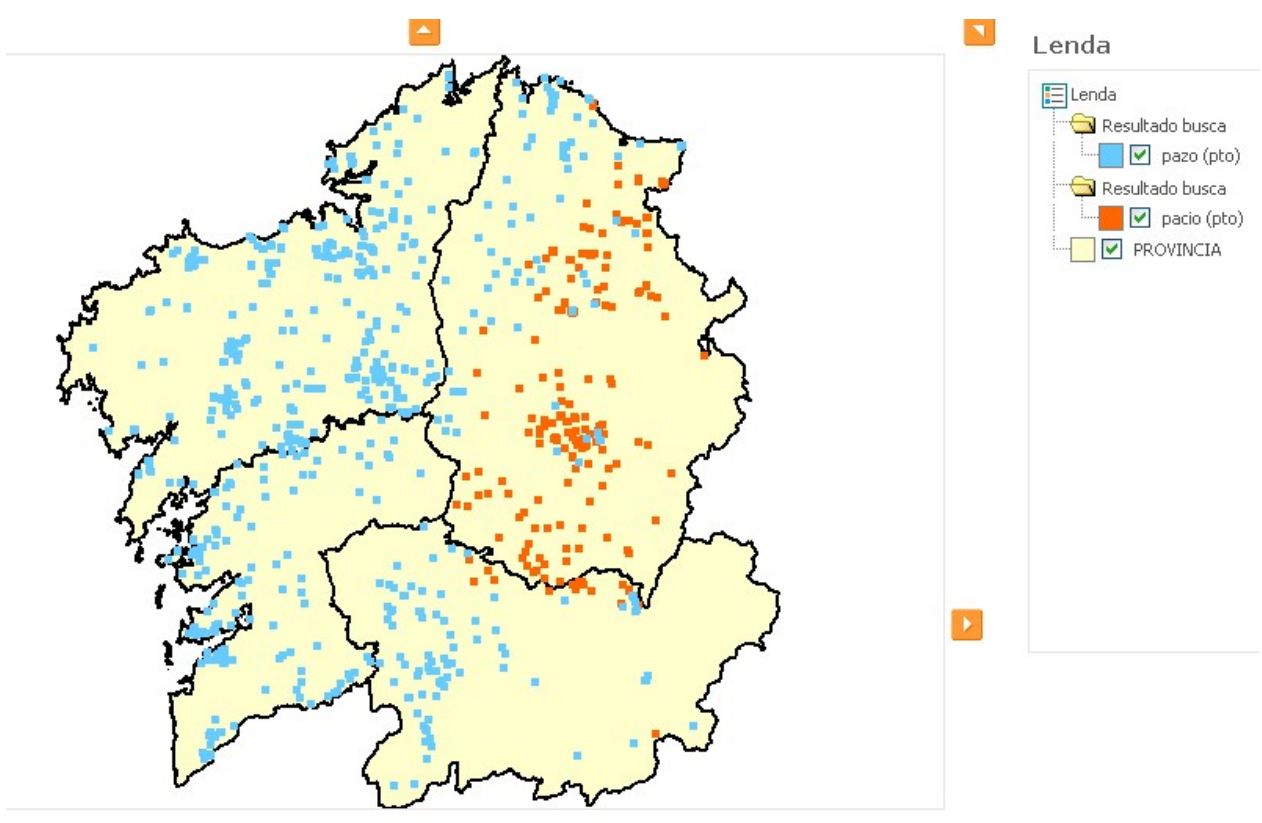

Fonte: PTG. ${ }^{19}$

${ }^{17}$ Hai moitas evidencias destas voces en secuencias referidas a edificacións ("soperatis, palatios, kasas" a.1085 Dozón, por exemplo); por iso parece menos probable a proposta de Juan José Moralejo (2008: 291-298), que lle supón orixe prerromana, a partir dun termo palatio 'curro, curral', con paralelo en varias linguas célticas (asax. faled, aing. falod 'cerrado para o gando').

${ }^{18}$ Entre o corpus Xelmírez e o GMH só localicei oito atestacións medievais de pacio(s) ou paçio(s) en textos notariais: 1270, 1272 e 1274 (Montederramo), 1400 (Monterroso), 1414, 1472 e 1478 (Lugo), 1486 (Mondoñedo). No entanto, aparecen 50 de paço(s)/paco/pazo.

${ }_{19}$ Elaborado a partir da ferramenta fornecida polo extinto Proxecto Toponimia de Galicia, actualmente fóra de funcionamento, substituído por Galicia nomeada (GN), que non permite elaborar mapas conxuntos de dúas formas distintas. 
Destacan neste grupo as referencias a construcións fortificadas ou sobranceiras. Entre elas, o castelo. Na Idade Media designa unha "edificación fortificada que servía de residencia real ou señorial" (VARELA SIEIRO, 2008, p. 148). Nos documentos escritos en latín os termos castrum e o seu diminutivo castĕllum son usados indistintamente para referirse tantos ós antigos castros coma ás fortificacións coetáneas. E en certo grao moitos dos castros foron escollidos como localizacións para construír castelos, por procuraren lugares altos, con boa visibilidade sobre os terreos circundante e as vías de comunicación e con características físicas que facilitaban a súa defensa. Existen restos de fortificacións (arredor dun cento) desde o séc. VI, que foron evolucionando ata apareceren os castelos, tal e como hoxe os figuramos, a partir do séc. XI. A súa motivación non foi tanto a defensa activa contra un inimigo externo (aínda que si nalgún caso, como as torres de Catoira contra os viquingos), como servir de instrumento do poder feudal ${ }^{20}$. Os nomes toponímicos da nosa listaxe que evidencian esas fortificacións son castelo e torre. Unha torre podía designar algo semellante a un castelo, parte das murallas, un torreón ou un campanario; en todo caso, “a tipoloxía destas construcións converteríaas nun elemento destacado da paisaxe", polo que a miúdo a súa utilización contextual na documentación ten un evidente valor demarcativo (VARELA SIEIRO, 2008, p. 188).

Pousada, probablemente elipse de uilla pausata (< supino de pausare 'deterse', 'descansar' ÁLVAREZ MAURÍN, 1994, p. 301), é palabra exclusiva da Península Ibérica. Segundo a documentación latina, parece designar unha construción de menor dimensión cá vivenda permanente, quizais destinada a habitación temporal de labradores ou pastores, próxima á explotación agraria. A partir desa acepción desenvolveuse a que hoxe ten nos dicionarios, ‘hospedaxe de características modestas onde habitualmente se aloxa xente que vai de paso' (DRAG), pero a que motivou os topónimos foi a primeira. Semellante é o

${ }^{20}$ Véxanse os traballos de Sánchez Pardo (2010b) e Lixó Gómez (2020).

51 № 71, NÚM. ESP.|2021, Salvador: pp. 38-75 
significado de cabana, tamén construción rústica, destinada neste caso ós apeiros, á protección do gando ou para gorecerse no campo (ÁLVAREZ MAURÍN, 1994, p. 303-4). Nos textos latinos do noroeste os testemuños na toponimia son moi anteriores á súa presenza como apelativo, que data do s. XIII (VARELA SIEIRO, 2006, p. 504). Procede do latín tardío capanna-, posiblemente de orixe celta ( Diccionario crítico etimológico castellano e hispánico, en diante DCECH, s.v. cabaña).

As explotacións agropecuarias están representadas polas voces granxa e graña. Corominas consideraba (DCECH s.v. granja) que granxa era un galicismo importado polos monxes do Císter, con orixe no latín vulgar granŭca. A hipótese fúndase no impulso que os cistercienses deron a estes establecementos; de feito, Xaime Varela (2008, p. 66) documenta a forma máis frecuente en territorio francés, grangia, exclusivamente nestes mosteiros (Sobrado, Oseira e Melón). En Galicia atopamos cerca de 600 atestacións de grangia (ou formas flexionadas ou derivadas) desde 1142 (en Sobrado), fronte a só sete de grania (desde 1192, en Toxosoutos). Con todo, Bascuas (2006) considera que tanto granxa coma graña poden interpretarse como un resultado duplo a partir do mesmo étimo, grania (do latín granea, derivado de granum), mediante un diferente proceso de silabación: gran-ia > granxa, gra-nia > graña, de forma paralela a Riaño / Rianxo ${ }^{21}$. Sexa evolución autóctona ou préstamo, a voz que acabou consolidada como común foi granxa, mentres que graña sobrevive unicamente como topónimo. A súa representatividade na toponimia maior é, con todo, semellante: 60 Graña(s) fronte a 83 Granxa(s).

Actualmente a voz parede (< lat. pares-etis, do clásico paries, -ětis) significa 'muro dunha construción', pero na Idade Media podía tamén referirse a un 'muro, valado, muralla' e, especificamente, ao 'valado que cerra e limita unha propiedade' (VARELA SIEIRO, 2008, p. 112-113). Este e mais o de 'ruínas de

${ }^{21}$ En todo caso, non está demostrado que o Rianxo galego teña esa orixe, pois na Idade Media sempre se documenta como Rianjo, mentres que o Riaño leonés consta como Riangulo en 924. 
construcións' (NAVAZA, 2007a, p. 138), son probablemente os que deron orixe ós topónimos, sempre en plural.

A importancia na vida económica da moenda, sobre todo do millo, maniféstase na abundancia da voz muíño (en moita menor medida a variante oriental muín). Designaba, igual ca hoxe, tanto o 'aparello para moer' coma a 'construción onde hai un muiño'. O seu valor toponímico increméntase dado que a miúdo foron utilizados para establecer os límites das propiedades (VARELA SIEIRO, 2006, p. 508).

Por último, o latín canalis 'conduto de auga', masculino en latín clásico, deixou descendentes de ambos os xéneros nas linguas románicas; no galego moderno o estándar é o xénero feminino, aínda que na toponimia vémolo tanto como feminino (A Canle 7, As Canles 1, A Cal 15, As Cales 2) como masculino (O Cal 29, O Canle 4). Canle usouse moito para denominar a canalización que leva a auga do río a un muíño (paralelamente a quenlla/quella < lat. canalicŭla) (NAVAZA, 2007a, p. 121). A outra variante, cal, tiña un significado máis xeral: 'leito artificial que se fai para que corra a auga' ou 'parte baixa do suco que fai o arado na terra' (DRAG). Hoxe na lingua estándar comparten esas dúas acepcións. Con esta voz hai elementos de intersección con outra das áreas estudadas, a auga (cap. 3); dado que se trata dunha construción artificial, decanteime por incluílo neste apartado.

\subsection{Vías: cruceiro, cruz, rúa, carreira, corredoira, parada, paradela}

Rúa, carreira e corredoira son claros topónimos viarios. O primeiro deles, rúa, tense considerado galicismo, pero Corominas (DCECH s.v. arruga) considérao palabra patrimonial, descendente regular do latín ruga. Do seu significado orixinario en latín 'engurra, pregadura, dobra', pasou a 'suco ou camiño fondo', e finalmente 'lugar público entre casas'. En textos galegos atopámolos desde o século XII (in rua Francorum [a actual rúa do Franco de 
Santiago] a.1135, rúa Nova a.1149, rúa de Valado [Noia] a. 1152, in rua publica a.1179 etc., vid. CODOLGA). Pola súa parte, carreira e corredoira son derivados de carro: 'camiño apto para carros'.

É imposible distinguir en topónimos como Cruceiro, Cruz se a motivación é relixiosa (a partir dunha cruz erixida no lugar) ou debida a unha encrucillada viaria, dado que, ademais, os cruceiros se chantaban nas interseccións dos camiños. O plural, Cruces, pode referirse a antigos marcos que sinalan demarcacións ou teren unha intención relixiosa, "como ofrenda ou recordatorio ou coa forma de calvario ou de via crucis" (NAVAZA, 2007a, p. 54). A cristianización destes lugares ten probablemente orixe en antigos cultos prerromanos, que ao romanizarse foron asimilados aos deuses Lares (divindades protectoras dos campos e dos aspectos domésticos e familiares), especialmente aos Lares Viais, protectores dos camiños: a maior parte das inscricións dedicadas a estas divindades atópanse na Gallaecia romana ${ }^{22}$.

Parada e o seu diminutivo Paradela considéranse habitualmente referidos a un lugar onde se facía un alto no camiño para descansar (pola configuración orográfica ou por outra causa) e para dar servizo aos animais que servían de transporte. Pero, como apunta Navaza (2007b, p. 30), hai significados antigos do verbo parar ('restaurar', 'reparar', existentes xa no verbo latino parare) que poden tamén ser motivación toponímica.

\section{A TERRA}

Na toponimia, a descrición dos distintos elementos do territorio baséase fundamentalmente na forma ou na composición do terreo. Habitualmente

${ }^{22}$ Das 36 inscricións dedicadas aos Lares Viais no mundo romano, só oito apareceron fóra da Gallaecia (delas, tres noutros lugares da península ibérica, catro en Europa e unha en África) (FRANCO MASIDE, 2002). 
denomínase orotoponimia ${ }^{23}$, e no noso corpus é o segundo grupo máis numeroso, cun $33 \%$ do total. Distingo catro categorías principais: a forma do terreo (elevacións, depresións, pendentes, chairas, ribeiras e accidentes xeográficos que facilitan a comunicación); a composición do terreo, segundo a súa calidade ou características; as pedras como elemento característico do terreo, e, finalmente, a descrición do terreo segundo o seu aproveitamento para faenas agrícolas ou gandeiras. No gráfico 3 pódese ver a proporción entre eles.

\section{Gráfico 3: A descrición dos elementos do territorio na toponimia}

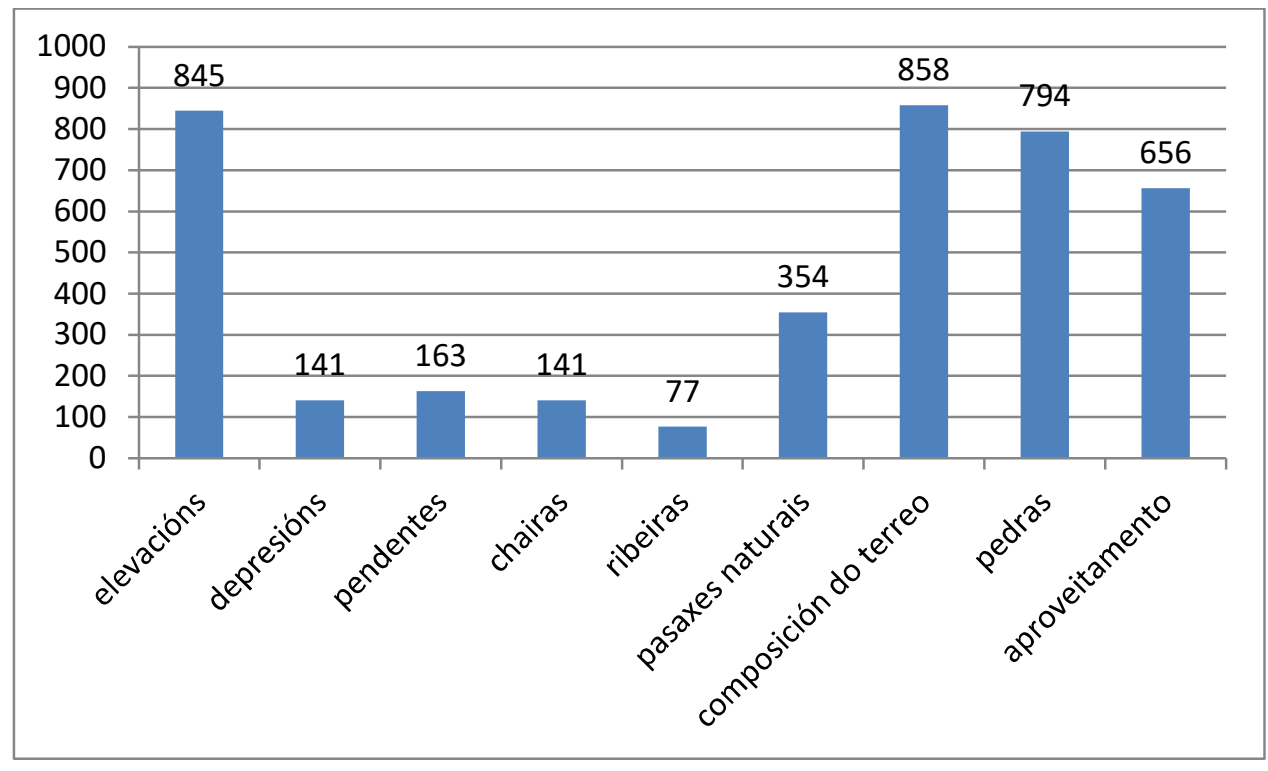

Fonte: elaboración propia

2.1 Formas do terreo: outeiro, coto, monte, porto, portela, costa, chan, val, ribeira

As elevacións son expresadas, sobre todo, coa palabra outeiro, que nomea a máis de medio millar de lugares. É unha voz característica do noroeste hispánico (galega e asturleonesa), e posiblemente sexa un derivado romance do

${ }^{23}$ Javier Terrado (1999, p. 84) propón xeonimia; no seu libro, referente sobre a investigación toponímica, establece unha cumprida clasificación sobre as distintas posibles categorías en que se pode plasmar esa realidade.

55 № 71, NÚM. ESP.|2021, Salvador: pp. 38-75 
descendente latino de altus co sufixo -eiro, como suxire Álvarez Maurín (1994, p. 88). Designa unha 'pequena elevación de terreo illada e de pouca extensión' (DRAG). Parecido significado ten coto 'parte máis alta dun monte, de forma cónica', voz de orixe prerromana ${ }^{24}$. En canto a monte, amais da acepción 'elevación importante do terreo' (DRAG), ten tamén o de 'terreo cuberto de vexetación espontánea como toxos, fentos, silvas, arbustos etc., que pode estar poboado de árbores'; nese sentido podería ser considerado como fitotopónimo, aínda que o seu uso toponímico é máis probable que proceda da súa condición de marca no relevo; en calquera caso, cumpriría unha análise concreta de cada lugar para dilucidalo.

Pertence tamén ás formas de relevo a costa (< lat. costa), que designa terreos ou treitos de camiño en pendentes máis ou menos pronunciadas. E o val (coa variante minoritaria vale) 'depresión de terreo xeralmente regada por un río', do latín vallis, de xénero feminino en latín (vallis ou valles); na toponimia consérvase así nalgúns $\operatorname{casos}^{25}$, pero o máis frecuente é que, coma no estándar actual, sexa masculino, debido ao influxo do contraposto mons, segundo Corominas. Hai que considerar que pode ter motivación distinta, xa que na Alta Idade Media tamén expresa unha circunscrición territorial, como en in ualle Nemitos uilla Melangos (a. 952, Sobrado), in ualle Sarrie uilla Iusano (a.955, Sobrado,) ou in valle Cornanda subtus monte Luanie (a. 1176, Toxosoutos), referidos ás xurisdición de Nendos, Sarria e Cornanda, respectivamente (vid. MARTÍNEZ LEMA, 2007).

O adxectivo latino planu-/plana- deu lugar en galego ao masculino chan/chao e ao feminino chan/chá, dependendo das áreas dialectais (as primeiras

\footnotetext{
${ }^{24}$ Segundo Menéndez Pidal (apud ÁLVAREZ MAURÍN, 1994, p. 93). Corominas (DCECH s.v. cueto) considérao de orixe incerta, e apunta a unha raíz expresiva. Hai que ter en conta que algúns dos coutos galegos (< lat. cautum) foron castelanizados como coto, e aínda poden figurar así en nomenclátores antigos ou na actual wikipedia en español, que castelaniza sistematicamente os topónimos galegos.

${ }^{25}$ A Val (As Neves, Po), A Valouta (Arbo, Po), Valcova (Becerreá, Lu), Valescura (Ortigueira, Co), Valboa (9) e sobre todo no diminutivo A Valiña (25 lugares no NG), As Valiñas (2).
}

56 № 71, NÚM. ESP.|2021, Salvador: pp. 38-75 
delas, grosso modo, corresponden ao terzo occidental do territorio). $\mathrm{Na}$ toponimia poden aparecer en singular (O Chao, O Chan, A Chan) ou en plural (Os Chaos, As Chans), en numerosos compostos (A Chan da Salgosa, Chan de Vila, Chaodarcas...), co xénero maioritariamente masculino (92 fronte a 41 femininos, dos que o levan expreso). En tódolos casos fai referencia a zonas caracterizadas por unha orografía plana, o que é certamente distintivo nun relevo tan accidentado coma o galego.

Algúns accidentes do terreo posibilitan superar obstáculos da orografía do terreo ou dun curso fluvial. Esa é a acepción toponímica do substantivo Porto (e do diminutivo do seu feminino, Portela), correspondente á segunda e á terceira acepción do DRAG. Por tanto, tamén podería considerarse topónimos viarios, porque están referidos a camiños. Téñase en conta aquí a dificultade en distinguir porto de porta nos compostos, onde só é evidente a presenza de porto pola aparente falta de concordancia (Portasouto, Portalodoso, Portagudiño, Portalamoso), porque en realidade mostran unha preposición ad (portu ad saltu, etc.).

Finalmente, un elemento xeonímico de difícil clasificación é ribeira, que algúns autores inclúen dentro dos hidrotopónimos (así GARCÍA ARIAS, 1995, p. 96). Dado que designa un terreo, por moito que estea a carón da auga parece máis conveniente situalo entre os orónimos.

\subsection{Composición do terreo: lama, barreiro, barral, veiga, varcia, gándara, bouza}

A maior variedade de voces que describen a composición do terro fan referencia á mestura da terra coa auga: lama 'masa branda que se forma ao mesturarse terra, area, follas etc., con auga' (DRAG), barreiro 'sitio de onde se extrae barro' e barral 'lugar onde hai moito barro', estas dúas últimas derivadas de barro e as tres de orixe prerromana (véxase DCECH). Hai que considerar, con todo, que barral podería remitir tamén a barra, outra palabra prelatina (cf. barreira, 
barronca, barranco...), e nese caso tería que ver coa orografía, como advirte Gonzalo Navaza (2007a, p. 43). De novo cómpre partir do topónimo concreto para decidilo.

As outras refírense á calidade do terreo desde o punto de vista da produción agrícola, sexa negativa (gándara e bouza) ou positiva (veiga, varcia), todas elas de orixe prelatina. Gándara (coas variantes granda e gandra) é un "terreo baixo, areento, húmido e improdutivo, onde só medra a maleza". Sobre a súa orixe etimolóxica tense especulado moito; Carlos BÚA, rigoroso e prudente estudoso das linguas prerromanas, considera que é inseparable de ganda 'acumulación de pedras' que tamén aparece en dialectos alpinos, e da que pode ser derivado co sufixo -ăra, presente noutros topónimos prelatinos (Láncara, Óutara, Guítara...), que engadiría un valor local-abundancial equivalente ao romance -eiro, co que significaría 'terreo onde hai grande cantidade de pedras'. Conclúe que é palabra de orixe non indoeuropea, non necesariamente de substrato, senón que puido incorporarse xa como préstamo á lingua céltica falada no noroeste peninsular (BÚA, 2019, p. 52-53). En canto a bouza "terreo inculto poboado de mato, como toxos, xestas, uces etc.", tamén ten orixe controvertida: véxase unha síntese en Navaza (2006, p. 3-95)

De signo contrario ás anteriores é veiga "terreo baixo, amplo e fértil, xeralmente ás beiras dun río" (DRAG). Carlos Búa (2017) fai un minucioso percorrido polas etimoloxías propostas para veiga e desbótaas con argumentos convincentes (incluída a vasca *(i)baica que propón Corominas), para inclinarse por unha "palabra prelatina * va(G)ica aplicada ás terras chás cultivables dos vales ben irrigados ou próximas aos ríos, que nese caso sería un derivado dunha palabra *va(G)o- ou similar que podería significar 'río', 'zona bañada polo río' ou algo semellante" (BÚA, 2017), pero, en todo caso, admitindo que non se pode chegar a unha conclusión segura. 
As variantes Barcia/Barxa 'terreo chan e fértil situado nas marxes dun río, que é frecuentemente anegado por este" (DRAG s.v. varcia) foron estudadas pormenorizadamente por Bascuas (2014) e conclúe que as dúas proceden, tras un proceso "enteiramente irregular", da raíz indoeuropea *aw(e)-, *awed-, *awer'humedecer, mollar, fluír', moi difundida na hidronimia europea, pero en ningunha parte tan arraigada coma en Galicia. A forma reconstruída que propón é *warkĭnā, cunha raíz *war- 'auga' que non está rexistrada por Pokorny como céltica, polo que debe ser paleoeuropea. A mesma orixe teñen o portugués várzea, vargem e o español bárcena. Á serie galega podiamos engadir os antigos diminutivos Barcela (7) e Barxela (9), e o máis moderno Barxiña.

\subsection{As pedras: pena, pedreira, fraga, laxe, seixo, penedo}

Un bo número de topónimos identifican pedras, case sempre en singular, en referencia a un exemplar ben visible na paisaxe. Teñen orixe no latín pena (< pŭnna), o seu derivado colectivo penedo, e mais seixo < saxu); é prerromana laxe (< lagĕna), probablemente celta, incorporada ó latín do noroeste hispánico.

Fraga procede do lat. fraga, pl. neutro de fragum 'lugar penedoso', derivado regresivo de fragosus 'áspero, escarpado, rochoso'. Por tanto, o seu significado orixinario refírese a un lugar onde abundan as pedras. Con esta acepción ou semellantes recóllese no surleste de Lugo, leste de Lugo e algún punto de León e Zamora, nos lugares máis abruptos do territorio galego. No seu estudo sobre esta voz, Fernández Rei, Bravo e Vázquez Freire (2006) relacionan o cambio de significado da voz fraga coa adaptación ás características orográficas do terreo: no norte do bloque central, onde o relevo é moito menos montañoso, especialmente na área mindoniense, fraga adquire o significado xeral de 'bosque, monte' (véxase os mapas das páxinas 376-377). Aquí temos en conta o seu significado orixinario, pero dependendo do lugar tamén podería ser clasificado como fitotopónimo, de maneira semellante ó que lle ocorría a monte. 
Pedreira é un obvio derivado de pedra e, polo seu significado, 'lugar de onde se extrae pedra, especialmente para ser usada na construción', está en relación co punto 1.2., referido ao aproveitamento humano dalgunha actividade (coma o muíño). Pero atendemos á súa máis probable motivación toponímica, a acepción 5 do DRAG, 'terreo cuberto de pedras', polo que o situamos aquí.

\subsection{O aproveitamento do terreo: campo, curral, devesa, couto, sisto}

Consideramos aquí aqueles termos que denotan partes do territorio que amosan que a súa principal motivación é a súa utilidade humana, o que os pon en relación co primeiro dos grupos establecidos. Tamén atopamos puntos concomitantes coa orotoponimia, xa que se refire fundamentalmente a campos de cultivo, delimitacións do chan ou actividades gandeiras.

Posiblemente o nome máis xenérico desta relación é campo. Do latín campus 'campo, chaira', refírese a un lugar chan, que se adoita dedicar ao cultivo, ou ben a un terreo onde nace herba espontaneamente. Sería posible tamén situalo no capítulo 2.1., onda as chairas, ou mesmo en 2.2., onda os terreos fértiles.

Directamente relacionado coa actividade gandeira está curral, 'espazo situado preto ou a carón da casa labrega, descuberto e xeralmente valado, onde se ceiban certos animais domésticos, se gardan os apeiros ou o carro, a leña ou o toxo etc.' (DRAG). Non debía ser moi distinto o uso dado na Idade Media, segundo a documentación (VARELA SIEIRO, 2006, p. 505). É voz de orixe discutida (véxase DCECH, s.v. corral, ÁLVAREZ MAURÍN, 1994, p. 289-90).

Un caso tamén algo diferente constitúeo couto, do lat. cautum 'disposición preventiva das leis' e despois 'terreo cercado' (DCECH s.v. coto I). Na documentación medieval aparece co sentido 'terreo sobre o que un señor ou un mosteiro exerce unha xurisdición, normalmente por concesión rexia, e cobra rendas ou prestacións en traballo', ou tamén como 'multa, pena pecuniaria' (BOULLÓN; MONTEAGUDO, 2009, p. 179). Hai moitos exemplos da primeira 
acepción: "notario jurado do couto do moesteiro de Santo Estevoo de Riba de Sil" a.1254, Mosteiro Ribas de Sil, "notario do couto de Meyra" a.1260, DocSponer, "moradores do casal do couto de San Johane de Poyo" a.1287, DocMaia. De aquí pode proceder o seu uso toponímico ${ }^{26}$, pero tamén ten outra acepción, derivada da anterior: 'terreo ou conxunto de terreos delimitados e reservados para algunha actividade' (DRAG)

A voz devesa (do latín tardío defensa 'defensa', na Idade Media 'prohibición', por referirse a un terreo acoutado) vén definida no DRAG como 'terreo extenso, poboado de árbores non moi mestas, normalmente valado ou cercado', se ben nalgunhas zonas do país significa tamén 'bosque de carballos' (DdD), o que a situaría máis propiamente no campo da fitotoponimia, a carón de souto. No seu significado orixinario designaba antigos espazos comunais de arboredo de aproveitamento restrinxido. Tiña uso comunal (para pastos, por exemplo), pero non se podía cortar leña, por estaren destinadas á construción naval para a monarquía. A partir do XVIII moitas pasaron a mans privadas, outras seguen a ser de man común e outras pasaron a designar núcleos de poboación (NAVAZA, 2007b, p. 39).

Adoitaba pórse en relación o topónimo Sisto cun nome persoal de orixe latina, procedente en última instancia do numeral sextus. Con todo, dado que como nome persoal non se documenta en homes galegos ata finais do século XIX, a súa abundancia no territorio e a presenza maioritaria de artigo (43 O Sisto fronte a 10 Sisto) fai pensar nun substantivo común, hoxe desaparecido. O proxecto

\footnotetext{
${ }^{26}$ A documentación histórica así o demostra nalgúns casos, coma no Couto (Outeiro de Rei) ou en Val do Couto (Paradela), segundo Nicandro Ares. Ás veces os modificadores parecen apuntar a un terreo cercado: O Couto Pequeno, O Couto de Baixo... Téñase en conta que tamén se utilizaba coutada e coutado para esta última acepción. En todo caso, na maior parte das veces cómpre un estudo específico de cada topónimo.

61 № 71, NÚM. ESP.|2021, Salvador: pp. 38-75 
Galicia nomeada sitúa estes topónimos por case toda Galicia, con excepción da provincia de Ourense e a zona máis meridional e oriental de Pontevedra ${ }^{27}$.

\section{Mapa 2: (O) Sisto na toponimia de Galicia}

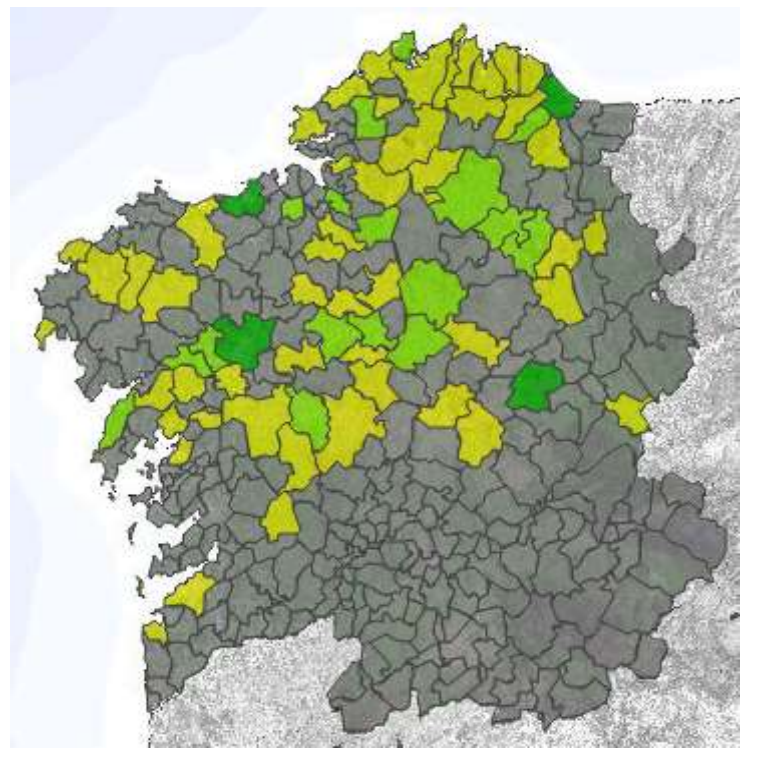

Fonte: Galicia Nomeada (GN).

Atopámolo na documentación galega desde os máis antigos textos (séc. VIII) ${ }^{28}$, e de alí en diante ininterrompidamente. Xa Joseph M. Piel (1988) advertiu a rareza desta familia e propuxo a voz latina ${ }^{*}$ sessitum 'asento, terra habitada en oposición a terras non poboadas', de sessitare, e este de sedere. Esta proposta ten problemas fonéticos: Piel explica o $i$ de sisto pola metafonía, pero se de *sessitum

\footnotetext{
${ }^{27} 187$ formas, en primeiro ou segundo lugar, pertencentes ao NG e tamén ao Proxecto Toponimia de Galicia, que inclúe unha recollida parcial da microtoponimia galega. A busca dos diminutivos Sistelo (6) e Sestelo (37) confirman esa distribución, coa excepción de 2 Sestelo no norte da provincia de Ourense (Vilamarín e A Peroxa). Piel (1988) cita sete ocorrencias de Sistelo e unha de Sistelos no norte de Portugal. No nomenclátor portugués moderno eu só atopo tres formas que poderían pertencer a esta familia: Cistelo (Viseu), Cestelo (Braga) e Sistelo (O Porto).

${ }^{28}$ Nos chamados documentos odoarianos transcritos no Tombo Vello de Lugo (vid. CODOLGA), e despois desde o séc. X ("loco predicto ubi dicimus Sisto" 910, Lugo), tamén como voz común: "inde in festo in sisto in penna ubi sedet cruce" 929, A Coruña, "de uereda que discurre de sisto pro ad fonte frida" 1073, Lugo. As formas con $e$ (sesto) son moito menos frecuentes, tanto na documentación antiga coma na toponimia moderna (8 Sesto(s) no NG).
} 
procede tamén o español siesto ${ }^{29}$, debería resultar / $/ \varepsilon$ en galego, e para explicar o i tónico esa metafonía debería actuar dous graos, o que é insólito.

Por outro lado, propuxérase a relación co verbo latino sistere 'establecer', referido a lugares de pastos, pero é difícil explicar como se chega á voz moderna. Segue a ser, por tanto, unha voz de orixe escura.

Inclúense aquí os topónimos relacionados coa auga, elemento omnipresente no territorio galego: amais de contar con cerca de $1.500 \mathrm{~km}$. de costa, a abundancia de precipitacións xera cunha gran cantidade de cursos fluviais, que inspiraron a Otero Pedrayo a denominación, adoito repetida, do "país dos mil ríos". Esta cifra non é esaxerada: Moralejo (2008, p. 103), estudoso da hidronimia prerromana, contabilizou unha cifra aínda meirande.

Como sinalamos no punto 1.2, falando de cal/canle, hai puntos de contacto co grupo dos topónimos referidos á intervención humana: fonte indica en principio un 'lugar onde mana auga, que pode proceder dunha corrente subterránea natural ou ser conducida artificialmente', e daquela pode designar unha construción onde foi canalizada a auga, sen coincidir necesariamente co manancial.

Rego e regueiro designan pequenos cursos de auga. Aínda que é evidente a semellanza co verbo latino rigare, que posiblemente se integrou nesta serie, para Corominas é indubidable que procede dun termo prerromano, ${ }^{*}$ rĕku, con influencia do céltico rǔca 'suco' (DCECH s.v. regar). Tamén designa cursos de auga a propia palabra río, de clara orixe latina (rivu), e mais rial, do adxectivo latino rivalis 'a carón do río, ribeirego', que puido confluír co tamén adxectivo latino regalis 'real, do rei', e indicar un reguengo (o topónimo O Real tamén pode 
ter calquera desas orixes). Aínda que sincronicamente sexa imposible desfacer esta homonimia, Bascuas (2002, p. 156) apóiase na escasa frecuencia desta última forma na documentación medieval en latín para apoiar a procedencia na maioría dos casos no derivado de rivus; moitos dos lugares así chamados, ademais, están situados á beira dun río e non están relacionados con reguengos medievais.

A lagoa vén definida no DRAG como "extensión de auga máis pequena ca o lago e de menor profundidade", pero na toponimia tamén pode designar un lugar facilmente inundable durante parte do ano. MATO, LIÑARES, PEREIRA, PEREIRO, PIÑEIRO, CARBALLO, NOGUEIRA, LOUREIRO

A maior parte das voces aquí indicadas teñen un significado colectivo, posto que é moi frecuente o conxunto arbóreo, visible mesmo a distancia. Por un lado, están as directamente derivadas de nomes de vexetais mediante o plural (liñares) ou con distintos sufixos colectivos (carballal, carballeira, reboredo). Para as que rematan en -eiro/a e coinciden co nome da planta (nogueira, pereira, pereiro, loureiro), Navaza afirma que tamén puideron ter en orixe un significado colectivo.

Outras expresan o conxunto mediante lexemas diferentes. Así souto (< latín saltu 'pastizais', 'pastizais con bosque'), que designa un 'terreo poboado de castiñeiros' (DRAG), aínda que o bosque pode estar poboado por outras árbores. A súa abundancia (é o primeiro dos fitotopónimos) fala da grande importancia que para a subsistencia tivo a castaña, sobre todo antes da chegada da pataca de América.

O outro lexema que expresa agrupación ${ }^{30}$ é mato, que hoxe designa, na terceira acepción indicada polo DRAG, 'conxunto espeso de matas ou maleza',

${ }^{30}$ Como dixemos, monte e fraga tamén podían indicar colectivos fitonímicos (véxanse os puntos 2.1 e 2.3 , respectivamente). 
seguramente a que orixinou os topónimos. É de orixe prerromana ${ }^{31}$, e competiu co termo latino silva, pero este en galego quedou limitado á denominación dun arbusto espiñento (rubus fruticosus) e é menos frecuente na toponimia (37 formas, con compostos).

A importancia das froitas exprésase mediante o colectivo pomar 'horta con árbores froiteiras', habitualmente maceiras; é un derivado do latín poma 'mazá'; a forma máis habitual na toponimia galega é pumar. As formas Pereira e Pereiro,

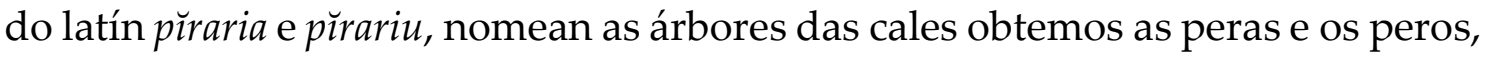
respectivamente. Eses étimos poden concorrer con petrario e petraria, adxectivos derivados de pětra 'pedra', aínda que na maioría dos topónimos presentan valor fitonímico.

Do latín pinariu, piñeiro é a denominación máis corrente para o que o DRAG define como 'arbore da familia das pináceas, de folla perenne en forma de agulla, que ten como froito a piña e como semente o piñón, e do cal existen varias especies'. Segundo Navaza (2006, p. 412), o feito de que o nome singular sexa máis frecuente na toponimia ca os derivados colectivos fai pensar que o común era que estas árbores se atopasen máis ben dispersas e non formando bosques.

A especie máis repetida é o xénero Quercus, particularmente o Quercus robur. Como di Gonzalo Navaza (2006, p. 151), “constitúe a realidade botánica máis importante da nosa fitotoponimia". Efectivamente, atopamos aquí carballo, carballal, carballeira (probablemente derivados dunha voz prerromana carba, vid. DCECH s.v. carba) e mais reboredo (< roboretu), o derivado colectivo do lexema latino, que xa non é voz común, esmagado pola vitalidade das palabras prelatinas. Amais destas, outras árbores apreciadas polo seu aproveitamento

\footnotetext{
31 Así o consideran Hubschmid e Antonio Tovar, apud Navaza (2006, p. 332), quen tamén comparte esa opinión. Corominas, recoñecéndoo como voz común ós romances hispánicos e a súa orixe incerta, suxire o latín tardío matta 'esteira', de onde "manchón de plantas que cubre cierta extensión del suelo" (DCECH s.v. mata).

65 № 71, NÚM. ESP.|2021, Salvador: pp. 38-75 
madeireiro son a nogueira (esta tamén polo froito) e o piñeiro; tamén se considera árbore o loureiro ${ }^{32}$.

A abundancia dos liñares (derivado de liño, e este do lat. linnu) na toponimia galega dá fe da importancia do liño na cultura tradicional, pois da planta extraíase materia téxtil para tecidos e cordeis, e as sementes aproveitábanse para facer aceite. O liño galego (Linum usitatissimum) tiña sona pola súa gran calidade.

\section{$5 \quad$ OS SANTOS}

A diferenza das clasificacións anteriores, estes topónimos non describen ningunha característica do territorio, senón que fan referencia ao sagrado. $\mathrm{O}$ nomenclátor de Galicia establece a división en provincias, concellos, parroquias e lugares. As parroquias (3.665) adoitan describirse como as unidades territoriais básicas da organización do territorio, e, de feito, temos noticias delas desde o século VI co célebre Parroquial Suevo ou Divisio Theodemiri33, onde se describen as trece dioceses que compoñían a organización eclesiástica do reino suevo. Cada parroquia ten unha advocación, e aproximadamente un $10 \%$ delas deron orixe a un haxiotopónimo, en cálculo de Gonzalo Navaza (2009, p. 182). Nesta aproximación só me refiro aos nomes dos lugares, non das parroquias, e aínda así, atopamos catro (San Pedro, san Martiño, san Xoán e santa Baia) que figuran entre os santos con máis advocacións parroquiais e que deron lugar a máis haxiotopónimos.

\footnotetext{
${ }^{32}$ Non ten aproveitamento madeireiro nin froiteiro, pero está asociado a crenzas positivas (vid. Eladio Rodríguez s.v., apud DdD); úsanse para facer sebes e tradicionalmente as follas quéimanse para afumar chourizos e, secas, como condimento.

${ }^{33}$ Moi estudado desde a metade do século pasado, citarei só unhas das últimas aproximacións a el feitas, a de SÁNCHEZ PARDO 2014, onde localiza os lugares alí citados á luz da arqueoloxía, as advocacións, a toponimia e a numismática.
}

66 № 71, NÚM. ESP.|2021, Salvador: pp. 38-75 
Táboa 2: os haxiotopónimos máis frecuentes nos lugares do NG

\begin{tabular}{|l|l|r|l|r|}
\hline orde & haxiotopónimo & $\begin{array}{c}\mathrm{n}^{\mathrm{o}} \text { de } \\
\text { advocacións } \\
\text { parroquiais }\end{array}$ & Outras formas con cadanseu $\mathrm{n}^{\mathrm{o}}$ & $\begin{array}{c}\mathrm{n}^{\mathrm{o}} \text { total } \\
\text { de } \\
\text { lugares }\end{array}$ \\
\hline $2^{\underline{0}}$ & San Pedro & 313 & Sampil 2 & 78 \\
\hline $4^{\underline{0}}$ & San Martiño & 238 & San Martín 7 & 93 \\
\hline $5^{\underline{0}}$ & San Xoán & 236 & $\begin{array}{l}\text { Seoane 52, Soane 1, Soanes1, } \\
\text { Seivane 4, Savane 3, Sevane } \\
1\end{array}$ & 74 \\
\hline $8^{\underline{a}}$ & Santa Baia & 138 & $\begin{array}{l}\text { Santalla 23, Santaia 7, } \\
\text { Santaballa 3, Santoalla 2, } \\
\text { Santa Eulalia 2 }\end{array}$ & 58 \\
\hline $19^{\underline{a}}$ & San Paio & 41 & Sampaio 1 & 58 \\
\hline
\end{tabular}

Fonte: elaboración propia ${ }^{34}$

Todos eles informan sobre a cronoloxía da fundación das parroquias, pois son das advocacións máis antigas, con culto atestado entre os cristiáns da Hispania romana e do período suevo e visigodo. A toponimización con base en nomes de santos foi parte do proceso de cristianización da paisaxe local (vid. GONZÁLEZ GARCÍA; GARCÍA QUINTELA, 2014, p. 459).

San Pedro, o nome do primeiro apóstolo de Xesús, é o segundo, despois de santa María, en número de advocacións. Presenta unha variante Sampil (2 lugares), debida, segundo Joseph M. Piel, á influencia da metafonía.

A difusión de San Martiño, coa variante noroccidental San Martín ${ }^{35}$, débese probablemente á devoción a san Martiño de Tours, apóstolo das Galias. O seu culto foi difundido na Gallaecia por outro san Martiño, dito de Dumio ou de Braga (séc. VI), disque responsable de cristianizar Galicia no tempo dos suevos, de forma definitiva, ou, como di Otero Pedrayo (1995, p. 82), “da maneira máis

\footnotetext{
${ }^{34}$ A orde de frecuencia das advocacións e o número de parroquias están tirados do cadro de Navaza (2009, p. 192). A información deste apartado procede fundamentalmente deste traballo e mais do de Piel (1949-1950).

${ }^{35}$ Os sete lugares que o presentan na súa composición están nos concellos de Cervantes, Baralla e a Fonsagrada. É a mesma zona onde se di camín ou vecín (< latín -īnus).
} 
definitiva que pode ser sometido o radical panteísmo dun pobo celta"36. Á súa difusión deberon contribuír as ordes relixiosas do Císter e Cluny a través do Camiño de Santiago. O día de san Martiño (11 de novembro) foi moi importante na sociedade tradicional: celébranse os magostos, próbase o viño novo e mátase o porco.

O San Xoán con máis devoción é o Bautista (xa testemuñado en Hispania no século VI), non o evanxelista, e coincide co solsticio de verán (24 de xuño), de novo unha apropiación de cultos anteriores; celébrase aínda hoxe con fogueiras nocturnas por todo o país. A forma máis difundida presenta unha evolución fonética patrimonial Seoane (< sanctu Iohanne), amais das minoritarias Seivane, Savane, e Sevane, Soane e Soanes; tamén hai 12 San Xoán, que ou ben son máis recentes cós anteriores ou foron castelanizados ${ }^{37}$.

Santa Baia foi mártir en Mérida a principios do séc. IV e converteuse na máis popular das santas hispánicas. A forma grecolatina da que procede, Eulalia 'que fala ben', deixou ata cinco variantes diferentes (Baia, Alla, Aia, Balla e Oalla); tamén hai dous casos do cultismo Santa Eulalia (en Taboada e Guntín).

\section{A REPERCUSIÓN ANTROPONÍMICA DESTES TOPÓNIMOS}

Case todos os topónimos estudados deixaron unha importante pegada no corpus dos apelidos galegos ${ }^{38}$. Os primeiros en número coinciden cos máis frecuentes dos apelidos detoponímicos de Galicia: Castro, Piñeiro, Pereira, Casal/Casar/Casais/Casás. Algúns deles coa forma castelanizada, de forma total ou

\footnotetext{
${ }^{36}$ De todas formas, a dúbida entre ambos santos ten raíces antigas e é persistente, como di Díaz y Díaz (apud GONZÁLEZ GARCÍA; GARCÍA QUINTELA, 2014, p. 461).

${ }_{37} \mathrm{O}$ criterio da Comisión de Toponimia cando unha forma transparente está castelanizada é restituír a forma estándar, se non existen testemuños da presenza da patrimonial. É o que xa se comentou no caso de Igrexa-Iglesia.

${ }^{38}$ Agás Igrexario (que, segundo Forebears, presenta 11 ocorrencias na Arxentina e 5 en España, da forma castelá Iglesario) e Cruceiro (Forebears rexistra 8 ocorrencias na Arxentina, 1 en Cuba, 1 en Guatemala e 1 en España). Recordemos que a Arxentina é un dos lugares de grande inmigración galega.
}

68 № 71, NÚM. ESP.| 2021, Salvador: pp. 38-75 
case total $^{39}$ : así, hai moi poucas ocorrencias de Igrexas ou Eirexas, pero miles de Iglesias, de Outeiro fronte ao maioritario Otero, Vila fronte a Villa, San Martín fronte a San Martiño, Granja fronte a Granxa. Noutros, a forma galega sobreviviu en maior proporción (Vilar-Villar, Vilares-Villares, Castelo-Castillo).

Outra das características da conversión dos topónimos en apelidos foi a adxunción da preposición de (contraída co artigo: $d o, d a)$, que en moitos casos se mantivo fosilizada na forma gráfica: así Davila, Dacosta, Dopazo/Dopacio, Doval, Domato, Dorrego, Dacal, Datorre, Dalama, Dacasa, Domonte. Tamén pode haber cambios gráficos: San Pedro e Sampedro, Sampaio, Sisto/Sixto.

A suma das ocorrencias deses apelidos posta en relación coa poboación de Galicia de 2001 (pois o CAG, de onde se toman os datos, é desa data), 2.695.880 persoas, e tendo en conta que en Galicia as persoas teñen legalmente dous apelidos, ofrece como resultado que arredor dun $12 \%$ da poboación de Galicia leva nos seus apelidos algún destes topónimos.

\section{CONCLUSIÓNS}

Historicamente os lugares en Galicia foron denominados a partir dos elementos considerados como máis identificativos. Os máis numerosos teñen que ver coa intervención humana (máis do $45 \%$ dos estudados): en primeiro lugar, as agrupacións humanas que formaban núcleos habitados, sempre de pequeno tamaño e con lixeiras variacións de significado ou tamaño (vila, vilar, vilariño, casal, quintá, quintela, aldea, quizais barrio), antigos núcleos defensivos (castro) agrupacións dentro dun núcleo (cima de vila), territorios con xurisdición eclesiástica (igrexario). Despois, as edificacións destinadas ao culto relixioso (igrexa, ermida), para vivenda habitual (casa), de menor calidade ou habitación

${ }^{39}$ A partir do século XVI, cando o galego foi desterrado da documentación escrita, algúns apelidos foron traducidos ao castelán ou deformados.

69 № 71, NÚM. ESP.|2021, Salvador: pp. 38-75 
temporal (pousada, cabana), de maior rango (pazo), instalacións defensivas (castelo, torre), agropecuarias (graña/granxa), hidráulicas (muíño, canle), e outras obras para establecer lindes (paredes). Por último, as vías, camiños acondicionados para o tránsito (carreira, corredoira), delimitados ó ámbito urbano (rúa) e lugares con condicións orográficas que facían necesario un descanso (parada). Dentro deste grupo teñen representación as encrucilladas, non só pola súa importancia na comunicación, senón tamén polo seu primitivo significado relixioso (cruz, cruceiro).

A toponimia terrestre supón case un 30\% deste corpus. Os elementos visibles no territorio máis rechamantes son as elevacións (outeiro, coto, monte) e as pasaxes naturais que salvan obstáculos para a comunicación (porto, portela). En moito menor medida están as pendentes (costa), as depresións (val), as chairas (chá) e as ribeiras. Tamén son moi definitorias as pedras, indicadas ás veces colectivamente (fraga, pedreira), pero en xeral indican, en singular, un elemento moi visible, ben polo tamaño, pola súa forma ou pola cor (pena, penedo, laxe, seixo). A composición do terreo describe terreos moi húmidos (lama, barreiro, barral), moi produtivos (veiga, varcia) ou ó contrario, infértiles ou incultos (gándara, bouza). O último dos grupos nomea o terreo utilizado para aproveitamento humano, con fin agrícola (campo), a miúdo delimitados (devesa, couto) e reservado para o gando (curral, acaso sisto).

A auga, posiblemente pola súa omnipresencia no país, non é dos referentes semánticos máis recorridos para nomear lugares (supón un 6\% do total do corpus analizado). A voz máis repetida é fonte, e despois diversas designacións de correntes de auga (río, regueiro, rego, rial) e unha de masa de auga (lagoa).

Os nomes referidos ás plantas supoñen un $10 \%$ deste conxunto. Varios son de colectivos (mato, souto, reboredo, carballal, carballeira, pomar (e fraga e monte se consideramos o seu valor fitonímico), outras de árbores (carballo, piñeiro, nogueira, 
loureiro), entre elas froiteiras (pomar, pereiro, pereira) e un cultivo para o aproveitamento téxtil (liñares). A cantidade de referencias ao Quercus robur é manifesta, tanto co lexema latino (reboredo) coma cos prerromanos (carballo, etc.).

Non hai zootopónimos nesta relación; vese que non son referencias tan estables coma as construcións humanas, os elementos orográficos ou o vexetal. Os animais máis nomeados na toponimia maior son as abellas e as curuxas, pero non chegan ós 50 topónimos, non sendo que se contasen tódolos derivados (curuxa, curuxeira, curuxal, curuxido...).

O derradeiro dos grupos considerados é o dos haxiotopónimos. O elemento relixioso non é exclusivo deles, como vimos antes ao mencionar a igrexa, as cruces e os cruceiros. Os santos máis nomeados na toponimia coinciden con algúns dos que teñen máis advocacións nas parroquias galegas e adoitan ser dos que teñen o culto máis antigo: son, por esta orde, San Martiño, San Pedro, San Xoán (maioritariamente coa forma patrimonial Seoane), Santa Baia e San Paio.

As bases etimolóxicas maioritarias son, como é esperable, as latinas (ou gregas ou hebreas transmitidas polo latín ${ }^{40}$ ), que acadan case o $85 \%$ de todos os considerados aquí. Os termos prerromanos, que non chegan ao 15\%, pertencen na súa maioría ao elemento oronímico, sexa referido á composición do terreo (barcia/barxa, bouza, gándara, lama, veiga, barral, barreiro), ao tipo de pedra (laxe) ou a elevacións (Coto). A seguir, os fitónimos: carballo (e carballeira, carballal), mato, hidrónimos (rego e regueiro, este último con evidente sufixación latina) e, por último, o discutido barrio, se se acepta a súa procedencia prelatina. A única palabra de orixe árabe é aldea, atestada no séc. XIII na documentación galega con esta acepción e que rapidamente alcanzou gran difusión.

En definitiva, os topónimos máis frecuentes do nomenclátor galego poñen de relevo os máis comúns núcleos e formas de poboamento medievais e as súas

${ }^{40}$ Nos haxiotopónimos: Baia, Paio e Xoán, respectivamente. A palabra igrexa (do lat. vg. ECLESĬA, cl. ecclesia), tamén procede en última instancia do grego. 
principais características naturais, principalmente no relativo á configuración, calidade e puntos máis visibles do terreo, así como algúns trazos non materiais, relativos á espiritualidade dos habitantes.

\section{REFERENCIAS}

ÁLVAREZ MAURÍN, M. Pilar. Diplomática asturleonesa. Terminología toponímica. León: Universidad, 1994.

BALLESTER, Xaverio. Amavida. Una introducción a la Arqueotoponimia. Valencia: Tilde, 2014.

BASCUAS, Edelmiro. Hidronimia y léxico de origen paleoeuropeo en Galicia. Sada: Edicións do Castro, 2006.

BASCUAS, Edelmiro. Novos estudos de hidronimia paleoeuropea galega. Vigo: Universidade de Vigo, 2014.

BOULLÓN AGRELO, Ana Isabel. Nomes, topónimos e apelidos: camiños de ida e volta. Guavira Letras, Três Lagoas, n. 25, p. 34-49, 2017.

BOULLÓN-AGRELO, Ana Isabel. O artificio das etimoloxías: elementos constitutivos da toponimia galega. In: CARRILHO, Ernestina; MARTINS, Ana Maria; PEREIRA, Sandra; SILVESTRE, João Paulo (orgs.). Estudos Linguísticos e Filológicos Oferecidos a Ivo Castro. Lisboa: Centro de Linguística da Universidade de Lisboa, 2019. p. 277-319.

BOULlÓN, Ana. Consideracións previas á selección do corpus toponímico (Toponomasticon Hispaniae). In: Actes de la XII Jornada d'Onomàstica de l'AVL normalització i investigació. València 2019. Publicacions de l'Acadèmia Valenciana de la Llengua, p. 37-44, 2020. Dispoñible en: [https://www.avl.gva.es/documents/31987/54305/Actes_21.pdf]. Accedido o: 30 de marzo de 2021.

BOULLÓN AGRELO, Ana Isabel; MONTEAGUDO, Henrique. De verbo a verbo. Documentos en galego anteriores a 1260. Anexo 65 de Verba. Anuario Galego de Filoloxía. Santiago de Compostela: Universidade de Santiago de Compostela, 2009.

BÚA, Carlos. Veigha: léxico e fonética da Galicia prelatina? In: BOULLÓN AGRELO, Ana Isabel (ed.). Estudar toponimia. Aproximacións metodolóxicas e interpretativas. Anexo 75 de Verba. Anuario Galego de Filoloxía. Santiago de Compostela: Universidade de Santiago de Compostela, 2017. p. 57-80.

BÚA, Carlos. Toponimia prelatina de Galicia. Anexo 78 de Verba. Universidade de Santiago de Compostela: Servizo de Publicacións, 2019.

CORRIENTE CÓRDOBA, Federico. Diccionario de arabismos y voces afines en iberorromance. Madid: Gredos, 1999. 
DCECH = COROMINAS, Joan; PASCUAL, José A. Diccionario crítico etimológico castellano e hispánico. 6 vols. Madrid: Gredos, 1980-1991.

FERNÁNDEZ REI, Francisco (coord.); BRAVO PÉREZ, Irene; VÁZQUEZ FREIRE, Maㅗ Luisa. A configuración do espazo a través do léxico: fragas, freitas e lameiros. In: ÁLVAREZ, Rosario; DUBERT, Francisco; SOUSA Xulio (eds.). Lingua e territorio. Santiago de Compostela: Consello da Cultura Galega; Instituto da Lingua Galega, 2006. p. 357-385.

FRANCO MASIDE, Rosa María. Lares viales na provincia de A Coruña. Gallaecia, Santiago de Compostela, n. 21, p. 215-222, 2002.

GARCÍA ARIAS, Xosé Lluis. Toponimia: teoría y actuación. Uviéu: Academia de la Llingua Asturiana, 1995.

GARCÍA QUINTELA, Marco, GONZÁLEZ GARCÍA, César, SEOANE VEIGA, Yolanda. De los solsticios en los castros a los santos cristianos: la creación de los paisajes cristianos en Galicia, Madrider Mitteilungen, n. 55, p. 443-485, 2014.

GARCÍA SÁNCHEZ, Jairo Javier. Los aspectos semánticos de la toponimia. In: Actes de la IV Jornada d'Onomàstica. Vila-real 2010. València: Acadèmia Valenciana de la Llengua, 2011, p. 177-188.

HERMO, Gonzalo. Arredor do topónimo como signo lingüístico. Guavira Letras, Três Lagoas, n. 25, p. 15-22, 2017.

HGN = PIEL, Joseph M.; KREMER, Dieter. Hispano-gotisches Namenbuch. Heidelberg: Carl Winter, 1976.

LIXÓ GÓMEZ, Carlos. O xurdimento dos castelos na Galiza medieval (ss. VIII-XIII). Tese de doutoramento. Universidade de Santiago de Compostela, 2020.

LÓPEZ CARREIRA, Anselmo. Historia de Galicia. Vigo: Edicións Xerais de Galicia, $2016^{3}$.

LÓPEZ FERREIRO, Antonio. Fueros municipales de Santiago y su tierra. Santiago de Compostela: Imp. del Seminario, 1895.

MARQUÉS VALEA, Xulia. A toponimia de Trabada. A Coruña: Real Academia Galega; Asociación Galega de Onomástica, 2018. [Colección Terra Nomeada].

MARTÍNEZ LEMA, Paulo. A clasificación semántica da toponimia. In: BOULLÓN AGRELO, Ana Isabel (ed.). Estudar toponimia. Aproximacións metodolóxicas e interpretativas. Anexo 75 de Verba. Anuario Galego de Filoloxía. Santiago de Compostela: Universidade de Santiago de Compostela, 2017. p. 37-56.

MORALEJO ÁlVAREZ, Juan José. Callaica Nomina: estudios de onomástica gallega. A Coruña: Fundación Barrié, 2008. p. 283-298.

NAVAZA, Gonzalo. Fitotoponimia galega. A Coruña: Fundación Barrié. Biblioteca Filolóxica Galega do Instituto da Lingua Galega, 2006. Dispoñible en: [http://ilg.usc.es/agon/wp-content/uploads/2010/09/Fitotoponimia_galega.pdf]. Accedido o: 30 de marzo de 2021.

NAVAZA, Gonzalo. Toponimia de Catoira. Catoira: Concello de Catoira, 2007a. 
NAVAZA, Gonzalo. Topónimos da parroquia de Rebordechán [Crecente-Po]. In: Rebordechán: A nosa memoria. [Vigo], Asociación Cultural Amistade, p. 13-68, 2007b.

NAVAZA, Gonzalo. Parroquias e toponimia. In: GARCÍA PAZOS, Fernando (coord.). A parroquia en Galicia. Pasado, presente e futuro. Santiago de Compostela: Xunta de Galicia, 2009. p. 181-201.

NAVAZA, Gonzalo. A intervenção régia na toponímia galega medieval. Os nomes de Afonso IX (1188-1230), Guavira Letras, Três Lagoas, n. 25, p. 50-78, 2017.

NAVAZA, Gonzalo. Retoponimizaciones regias medievales en el noroeste peninsular. In: CASANOVA, Emili (ed.). Actes de la XII Jornada d'Onomàstica de l'AVL normalització $i$ investigació. València 2019. Publicacions de l'Acadèmia Valenciana de la Llengua, p. 113121, 2020.2 Dispoñible en: [https://www.avl.gva.es/documents/31987/54305/Actes_21.pdf]. Accedido o: 30 de marzo de 2021.

OTERO PEDRAYO, Ramón. Ensaio histórico sobre a cultura galega. Vigo: Galaxia, 1995.

PIEL, Joseph M. Os nomes dos santos tradicionais hispânicos na toponímia peninsular. Biblos, Coimbra, n. 25, p. 287-353, 1949; n. 26, p. 281-314, 1950.

PIEL, Joseph M.. Uma numerosa família toponímica galego-portuguesa de origem obscura: Sesto/Sexto, Sisto/Sixto, Sestín, Sestelo, etc.. In: Centro de Estudos Geográficos. Vol. II. Livro de homenagem a Orlando Ribeiro. Lisboa: Universidade de Lisboa, 1988. p. 4954 .

PORTELA FILGUEIRAS, María Isabel. Los dioses lares en la Hispania romana. Lucentum, San Vicente del Raspeig, n. 3, p. 153-180, 1984.

SÁNCHEZ PARDO, José Carlos. Castros y aldeas galaicorromanas: sobre la evolución y transformación del poblamiento indígena en la Galicia romana. Zephyrus, Salamanca, n. 65, p. 129-148, 2010a.

SÁNCHEZ PARDO, José Carlos. Castros, castillos y otras fortificaciones en el paisaje sociopolítico de Galicia (siglos IV-XI). In: QUIRÓS CASTILLO, Juan Antonio; TEJADO SEBASTIÁN, José María (eds.). Los castillos altomedievales en el noroeste de la Península. Bilbao: Universidad del País Vasco, 2010b, p. 29-55.

SÁNCHEZ PARDO, José Carlos. Organización eclesiástica y social en la Galicia tardoantigua. una perspectiva geográfico-arqueológica del Parroquial Suevo. Hispania Sacra, [S. l.], v. 66, n. 134, p. 439-480, julio-diciembre 2014.

SANTAMARINA, Antón. A pegada relixiosa na toponimia galega. I. Edificios relixiosos. In: AXEITOS, Xosé Luís, GRANDÍO SEOANE, Emilio, VILLARES, Ramón (eds.). A patria enteira: Homenaxe a Xosé Ramón Barreiro Fernández. Santiago de Compostela: Consello da Cultura Galega; Real Academia Galega; Universidade de Santiago, 2008. p. 935-949.

SANTAMARINA, Antón. A historiografía da toponomástica na Romania. In: BOULLÓN AGRELO, Ana Isabel (ed.). Estudar toponimia. Aproximacións metodolóxicas e interpretativas. Anexo 75 de Verba. Anuario Galego de Filoloxía. Santiago de Compostela: Universidade de Santiago de Compostela, p. 9-36, 2017. 
TERRADO PABLO, Javier. Metodología de la investigación en toponimia. Zaragoza: INO Reproducciones, 1999.

TRAPERO, Maximiano. Para una teoría lingüística de la toponimia (Estudios de toponimia canaria). Gran Canaria: Universidad de Gran Canaria, 1995.

VARELA SIEIRO, Xaime. Léxico cotián na alta Idade Media de Galicia: a arquitectura civil. Anexo 62 de Verba. Santiago de Compostela: Universidade de Santiago de Compostela, 2008.

\section{Recursos en liña}

CAG = Cartografía dos apelidos de Galicia . Dirs: Ana Boullón / Xulio Sousa. Instituto da Lingua Galega. USC. Dispoñible en: [http://ilg.usc.es/CAG/]. Accedido o: 30 de marzo de 2021.

CODOLGA $=$ Corpus Documentale Latinum Gallaeciae . Centro Ramón Piñeiro para a Investigación en Humanidades. [http://corpus.cirp.es/codolga/]. Accedido o: 30 de marzo de 2021.

Corpus Xelmírez. Corpus lingüístico da Galicia medieval. Coord.: Xavier Varela Barreiro. Instituto da Lingua Galega. USC. Dispoñible en: [http://sli.uvigo.es/xelmirez/]. Accedido o: 30 de marzo de 2021.

$\mathrm{DdD}=$ Dicionario de dicionarios. Dir.: Antón Santamarina. Instituto da Lingua Galega. USC. Dispoñible en: [http://sli.uvigo.es/DdD/index.html]. Accedido o: 30 de marzo de 2021.

DRAG = Dicionario da Real Academia Galega. Dispoñible en: [https://academia.gal/dicionario]. Accedido o: 30 de marzo de 2021.

Forebears. Genealogy portal. Dispoñible en: [https://forebears.io/surnames]. Accedido o: 30 de marzo de 2021.

$\mathrm{GMH}=$ Gallaecia Monumenta Historica. Dispoñible en: [http://gmh.consellodacultura.org/]. Accedido o: 30 de marzo de 2021.

GN = Galicia nomeada. Real Academia Galega - Xunta de Galicia. Dispoñible en: [https://galicianomeada.xunta.gal/sixtop/visor]. Accedido o: 30 de marzo de 2021.

NG = Comisión de Toponimia da Xunta de Galicia (2003): Nomenclátor de Galicia. Xunta de Galicia. Consellería da Presidencia. Dispoñible en: [http://www.xunta.es/nomenclator]. Accedido o: 30 de marzo de 2021.

Nota do editor:

Artigo submetido para avaliação em: 30 de março de 2021.

Aprovado em sistema duplo cego em: 27 de junho de 2021.

75 № 71, NÚM. ESP.|2021, Salvador: pp. 38-75 